\title{
Effect of Some Growth Regulators, Nutrient Elements and Kaolin on Cracking and Fruit Quality of Pomegranate 'Wonderful' Cultivar
}

\author{
Harhash, M. M. ${ }^{1}$, M. A. M. Aly ${ }^{1}$, Nagwa A. Abd El-Megeed ${ }^{2}$ and A.B.S. Ben \\ $\mathrm{Hifaa}^{3}$ \\ ${ }^{1}$ Plant Production Dept. Faculty of Agriculture (Saba Basha) Alexandria University. \\ ${ }^{2}$ Hort. Res. Institute, Agric. Res. Center, Giza, Egypt. \\ ${ }^{3}$ Postgraduate student.
}

\begin{abstract}
This study was carried out during two successive seasons 2016 and 2017 on six years old 'Wonderful' pomegranate trees (Punica granatum L.). Trees were grown on sandy loam soil conditions in a private orchard located at Burg El-Arab, Alexandria governorate, Egypt. The trees were spaced $4 \times 5 \mathrm{~m}$ apart and irrigated by drip irrigation system and received similar cultural practices adapted in the orchard. The effect of some growth regulators, nutrient elements and kaolin on cracking and fruit quality of pomegranate 'Wonderful' cultivar was studied. The experiment was designed as randomized complete block design with five replicates. Each block contained 11 treatments (control, naphthalene acetic acid (NAA) at 25 and $50 \mathrm{mg} / \mathrm{l}$, gibberellic acid $\left(\mathrm{GA}_{3}\right)$ at 100 and $150 \mathrm{mg} / \mathrm{l}$, boric acid at $0.1 \%$ and $0.3 \%$, calcium chloride at $1 \%$ and $2 \%$ and kaolin at $4 \%$ and $6 \%$ ). Results revealed that, boric acid at $0.3 \%$ gave the highest mean values of fruit set (\%), number of fruits/tree, yield $(\mathrm{kg} / \mathrm{tree})$ and anthocyanin; while, naphthalene acetic acid at $50 \mathrm{mg} / \mathrm{l}$ recorded the maximum mean values of fruit weight, fruit diameter, volume and grain weight, and gave the minimum mean values of fruit drop and fruit cracking (\%). On other hand, gibberellic acid $\left(\mathrm{GA}_{3}\right)$ at $150 \mathrm{mg} / \mathrm{l}$ gave the maximum yield $(\mathrm{kg} / \mathrm{tree})$, in the second season and the minimum fruit cracking (\%), whereas, calcium chloride at $2 \%$ gave the best results of TSS (\%), acidity (\%), and vitamin C, total and reducing sugars were higher than the control for all treatments. Finally, kaolin at $6 \%$ gave the lowest percentage of sunburn and the highest percentage of juice, as compared with the control and other treatments during both seasons.
\end{abstract}

Keywords: Pomegranate 'Wonderful', NAA, $\mathrm{GA}_{3}$, calcium chloride, boric acid, kaolin, fruit set, fruit cracking, fruit sunburn, yield, fruit quality.

\section{INTRODUCTION}

Pomegranate (Punica granatum L.) is a fruit tree of the Punicaceae family, which is mainly grown in subtropical and tropical regions (Adsule and Patil, 1995; Naik and Chand, 2011). Pomegranate fruits are consumed fresh or processed, and they are considered as a healthy food because of the high content of antioxidant compounds (Legua et al., 2012).

In Egypt, the total cultivated area of pomegranate is 34450 feddan with total fruit production of 106260 tons, according to the latest statistics of the Ministry of Agriculture and Land Reclamation (2013).

Pomegranate peel extracts have been found to be suitable for applications in the food industry as they are an important source of phenolics, flavonoids and tannins occurring as natural ingredients and co-products of pomegranate juice PJ-related preparations (Viuda-Martos et al., 2010 and 2013). It is well known that pomegranate is a good source of anti-oxidants. 
However, as Salgado et al. (2012) have shown the anti-oxidant content of other juices such as tomato and orange juice with strawberries can also be improved by the addition of as much as $0.5 \%$ dried pomegranate peel extracts to the juice.

Pomegranate responses well to $\mathrm{Ca}$, B to increase fruit yield, fruit weight and considerably decreases cracking which is one of the major disorders of pomegranate (Khalil and Aly, 2013).

Boron roles in plants include effects on the germination of pollen grains, the elongation of pollen tube, fruit set and yield, and is also indirectly responsible for the activation of dehydrogenase enzymes, sugar translocation, nucleic acids and plant hormones (El-Sheikh et al., 2007 and Marschner, 2012).

The application of a kaolin particle film reduces fruit temperature with tools of evaporative cooling and fewer direct sunlight happening on fruit surface. Decrease in fruit surface temperature can be correlated to the amount of kaolin residue on the fruit surface (Glenn and Prado, 2002). A 5 to $10^{\circ} \mathrm{C}$ decrease in midday fruit surface temperatures by a kaolin based particle film was reduced almost $100 \%$ in some studies and had no effect in others, while the general trend was around a 50\% decrease in sunlight impelled fruit damages which varied by location and cultivar (Glenn and Puterka, 2005).

Gibberellic acid was widely used in various horticultural crops for improving fruit set, fruit weight and dimensions, aril \%, firmness, peel thickness, yield and its components, total sugars, vitamin $\mathrm{C}$, total anthocyanins and total soluble solids percentage (Khalil and Aly, 2013 and Merwad et al., 2016). Spraying pomegranate with various concentrations of $\mathrm{GA}_{3}$ reduced the percentage of fruit cracking (El-Mahdy et al., 2009 and Hegazi et al., 2014).

Naphthalene acetic acid (NAA) is a synthetic auxin plant hormone that is routinely used for the vegetative propagation, flowering and fruiting in many fruit crops. The effect of NAA on plant growth is greatly dependent on the time of application and concentration. NAA has been shown to greatly increase cellulose fiber formation in plants. In majority of fruit plants, fruit drop is controlled by spraying of NAA in different concentrations. It is applied after blossom fertilization (Suman et al., 2017).

Fruit cracking is a serious problem of pomegranate. It is due to boron deficiency in young fruits while in developed fruits it may be caused due to extreme variations in day and night temperatures. Boron and calcium were highly effective in improving, nutritional status, yield and fruit quality of pomegranate trees. Foliar application of boron reduced the percentage of cracked fruits (Khalil and Aly, 2013).

Cracking damage is one of the most serious problem faces pomegranate growers. It causes loss about $50 \%$ of the marketable fruits. This problem is due to the improper water management and deficiency of micronutrients and $\mathrm{Ca}$ (Sheikh and Manjula, 2012). Calcium plays an important role in reducing fruit 
cracking; it improves fruit growth and creates a state of water balance between pericarp and inside fruit tissues, as well as maintains fruit cell wall elasticity and firmness (Mitra, 1997). Applying calcium before harvest improves various fruits quality (Pooviah, 1979 and Cheour et al., 1990). Among different elite horticultural practices, growth regulators have been advantageously used recently to increase the fruit production and to improve the quality of several fruit crops (Cline and Trought, 2007, Amezquita et al., 2008, Canli et al., 2015). The effects of applying $\mathrm{GA}_{3}$ on the pomegranate plants to improve plant growth, yield, fruit quality parameters and lessening of cracking as well as the retardation of maturity have been studied (Ameen Al-Imam, 2009 and Khalil and Aly, 2013).

The aim of this study was to examine the effect of some growth regulators ( $\mathrm{GA}_{3}$ and $\mathrm{NAA}$ ), nutrient elements (boric acid and calcium chloride) and kaolin on cracking, sunburn, drop, yield and fruit quality of cv. 'Wonderful' pomegranate trees.

\section{MATERIALS AND METHODS}

This study was carried out during two successive seasons 2016 and 2017 on six years old 'Wonderful' pomegranate trees (Punica granatum L.). Trees were grown on sandy loam soil conditions in a private orchard located at Burg El-Arab, Alexandria governorate, Egypt. The trees were spaced 4x5 $\mathrm{m}$ apart and irrigated by drip irrigation system and received similar cultural practices adapted in the orchard. During the entire seasons, N, P and $\mathrm{K}$ fertilizer were added through drip irrigation system four times per week at a rate of $70 \mathrm{~N}$ unit/feddan in the form of ammonium sulphate $(20 \% \mathrm{~N}), 100 \mathrm{~K}$ unit/feddan as potassium sulphate $\left(48 \% \mathrm{~K}_{2} \mathrm{O}\right)$ and $30 \mathrm{P}$ unit/feddan as sulphoric acid $(60 \%$ $\mathrm{P}_{2} \mathrm{O}_{5}$ ).

\section{Experimental design}

The experiment was arranged in randomized complete block design on 55 trees as 11 treatments were applied and each treatment comprised of five trees arranged randomly in blocks.

The treatments can be illustrated as follows:

1- Control (Spraying with water).

2- $25 \mathrm{mg} / \mathrm{l}$ Naphthalene acetic acid (NAA).

3- $50 \mathrm{mg} / \mathrm{l}$ Naphthalene acetic acid (NAA).

4- $100 \mathrm{mg} / \mathrm{l}$ Gibberellic acid $\left(\mathrm{GA}_{3}\right)$.

5- $150 \mathrm{mg} / \mathrm{l}$ Gibberellic acid $\left(\mathrm{GA}_{3}\right)$.

$6-0.1 \%$ Boric acid $(17 \% \mathrm{~B})$.

7- $0.3 \%$ Boric acid $(17 \% \mathrm{~B})$.

8 - $1 \%$ Calcium chloride (34\% Ca).

9- $2 \%$ Calcium chloride (34\% Ca).

10- 4\% Kaolin.

11- 6\% Kaolin. 


\section{Data recorded}

\section{A) Fruit set and drop (\%):}

- Fruit set (\%):

Sixty days after flowering, final fruit set percentage was calculated in the same sequence mentioned above for the initial fruit set percentage according to this formula (Westwood, 1978).

$$
\text { Fruit set }(\%)=\frac{\text { No. of fruitlets }}{\text { No. of opened flowers }} \times 100
$$

- Fruit drop (\%):

Fruit drop \%: was calculated by counting the number of dropping fruits from the middle of June till the commercial harvesting time under experimental conditions, then expressed as a percentage from the whole number of fruits remained on the tree at the middle of June according to this formula:

$$
\text { Fruit drop }(\%)=\frac{\text { No. of dropped fruits }}{\text { No. of set fruitlets }} \times 100
$$

- $\quad$ ruit cracking (\%):

The percentage fruit cracking per tree was calculated before harvest time. The number of cracking fruits was counted on each tree and the percentage of fruit spilt was calculated according to the equation:

$$
\text { Fruit cracking }(\%)=\frac{\text { Number of cracked fruits } / \text { tree }}{\text { Total number of fruits } / \text { tree }} \times 100
$$

- Fruit Sunburn (\%):

Fruit sunburn status was estimated as the percentage of sunburned fruits on each tree relative of the total number of fruits on the tree just before harvest according to Schupp et al. (2002) as:

$$
\text { Sunburn }(\%)=\frac{\text { Number of sunburn fruits } / \text { tree }}{\text { Total number of fruits } / \text { tree }} \times 100
$$

\section{B) Yield (kg/tree):}

At harvest date in beginning of October (190 days after flowering in both seasons), the number of fruits per tree in each treatment was counted and fruit yield in ( $\mathrm{kg} / \mathrm{tree})$ was calculated.

The produced fruit yield on each replicate tree resulting from applied treatments was expressed as number of fruits/tree and weight of fruits ( $\mathrm{kg} / \mathrm{tree})$ which was attained mature stag.

\section{C) Physical fruit characteristics:}

At harvest time, sample of 10 fruits per tree from each replicate was collected randomly, then transported to the laboratory of Plant Production Department, Faculty of Agriculture (Saba Basha), Alexandria University to determine its quality as follows: 
- Fruit weight (g)

-Fruit length (cm)

- Fruit diameter $(\mathrm{cm})$

- Fruit volume $\left(\mathrm{cm}^{3}\right)$

- Juice $(\%)$

D) Chemical fruit characteristics:

Regarding chemical fruit characteristics, samples of 10 fruits from each replicate tree i.e. 50 fruits for each of the applied treatment were picked randomly at harvest to determine the following parameters:

- Total soluble solids (TSS \%): was used to determine the percentage of TSS by hand refractometer according to Chen and Mellenthin (1981).

- Total acidity (\%): was determined in fruit juice according to Chen and Mellenthin (1981). Five milliliters from the obtained juice were used to determine the titratable acidity. The titratable acidity was expressed as mg citric acid/100 milliliters fruit juice.

- Total sugars (\%): were determined in fresh fruit samples according to Malik and Singh (1980). Sugars were extracted from 5 gram fresh weight and determined by phenol sulfuric and Nelson arsenate-molybadate colorimetric methods for total and reducing sugars, respectively. The non-reducing sugars were calculated by difference between total sugars and reducing sugars.

- Vitamin C (mg/100 ml juice): The ascorbic acid content of the juice was determined by titration with 2, 6- dichloro phenol-indo-phenol (AOAC, 1985) and calculated as milligrams per $100 \mathrm{ml}$ of juice.

- Anthocyanin content $(\mathrm{mg} / 100 \mathrm{~g})$ : Anthocyanin content was determined at the stage of coloration (mg/100g fresh weight) according to Rabino et al. (1977).

\section{Statistical analysis:}

Results of the measured parameters were subjected to computerized statistical analysis using MSTAT package for analysis of variance (ANOVA) and means of treatments were compared using LSD at 0.05 according to Snedecor and Cochran (1990).

\section{RESULTS AND DISCUSSION}

\section{A) Fruit set and drop (\%):}

- Fruit set (\%):

The observations on fruit set (\%) in pomegranate as influenced by growth regulators, nutrient elements and kaolin are given in Table (1). Data showed that fruit set \% increased significantly by most treatments and the maximum fruit set $(25.26$ and $19.55 \%)$ was recorded by foliar application of $0.3 \%$ boric acid, which was significantly superior to all other treatments and was closely followed 
by foliar application of $0.1 \%$ boric acid (24.54 and $17.38 \%$ ), during both seasons 2016 and 2017, respectively. The minimum fruit set (14.56 and 10.49 $\%$ ) was observed on untreated trees (control) which was significantly lower than most other treatments in 2016 and 2017 seasons. These results are in agreement with those obtained by Saadati et al. (2016) and Hikal et al. (2017). The present results indicated increasing fruit set with boric acid treatment compared with control treatment may attribute to role of boron in maintaining high pollen viability, germination and pollen tube cellulose elongation (Hassan, 2000).

- Fruit drop (\%):

Data in Table (1) indicated that all foliar application treatments significantly reduced fruit drop as compared with the control and that control treatment recorded significantly highest the fruit drop percent (15.18 and 16.79 $\%$ ), while, the lowest fruit drop (\%) was observed in $50 \mathrm{mg} / \mathrm{l}$ NAA (4.96 and 6.33 $\%)$, respectively, during both seasons. These results are agreement with those obtained by Prajapati et al. (2016) and Suman et al. (2017). The auxins and gibberellins are used to control the fruit drop on citrus for improving the quality of fruit Almeida et al. (2004).

\subsubsection{Fruit cracking (\%):}

It is clearly evident from the data in Table (1) that all treatments significantly decreased fruit cracking and the maximum fruit cracking (9.96 and $13.84 \%$ ) was observed by control treatment, in the first and second seasons, respectively. The minimum fruit cracking (4.66 and $4.65 \%$ ) recorded by treatment $50 \mathrm{mg} / \mathrm{l} \mathrm{NAA}$, in the first and second seasons, respectively. These results are in agreement with those obtained by Yilmaz and Özgüven (2016) and Kumar et al. (2017). Calcium is the most important mineral nutrient for the mechanical resistance and stability of the cell structure of fruit. In the calcium deficiency, middle lamellae enlarge, thin out and then cracking (Asgharzade and Babaeian, 2012). The effect of $\mathrm{Ca}$ application in decreasing pomegranate fruit cracking has been attributed to the role of $\mathrm{Ca}$ in the cohesion of cell walls, since it interacts with pectic acid (Bakeer, 2016).

\subsubsection{Sunburn (\%):}

Data given in Table (1) revealed that sunburn percentage significantly was decreased by all treatments in comparison with the control and maximum sunburn (11.32 and $11.79 \%$ ) was observed by control treatment, in both years. The minimum sunburn (4.66 and $4.26 \%$ ) was recorded by treatment $6 \%$ Kaolin, in the first and second seasons, respectively. These results are agreement with those obtained by Ennab et al. (2017) and Mozaffarifard et al. (2017). The successful use of the Kaolin based sunscreen Surround to reduce losses in pomegranates due to sunburn has been reported by Melgarejo et al. (2004). 
Table (1). Response of 'Wonderful' pomegranate fruit set, fruit cracking and sunburn percentages, to foliar application of some growth regulators, nutrients elements and kaolin treatments during 2016 and 2017 seasons

\begin{tabular}{|c|c|c|c|c|c|c|c|c|}
\hline \multirow{3}{*}{ Treatments } & \multicolumn{2}{|c|}{$\begin{array}{c}\text { Fruit set } \\
(\%)\end{array}$} & \multicolumn{2}{|c|}{ Fruit drop (\%) } & \multicolumn{2}{|c|}{$\begin{array}{c}\text { Fruit cracking } \\
(\%)\end{array}$} & \multicolumn{2}{|c|}{$\begin{array}{c}\text { Sunburn } \\
(\%)\end{array}$} \\
\hline & & & & Seaso & & & & \\
\hline & 2016 & 2017 & 2016 & 2017 & 2016 & 2017 & 2016 & 2017 \\
\hline Control & $14.56^{\mathrm{d}}$ & $10.49^{\mathrm{de}}$ & $15.18^{\mathrm{a}}$ & $16.79^{\mathrm{a}}$ & $9.96^{\mathrm{a}}$ & $13.84^{\mathrm{a}}$ & $11.32^{\mathrm{a}}$ & $11.79^{\circ}$ \\
\hline $25 \mathrm{mg} / \mathrm{l} \mathrm{NAA}$ & $12.78^{\mathrm{d}}$ & $9.43^{\mathrm{e}}$ & $7.38^{\mathrm{e}}$ & $7.64^{\dagger}$ & $5.14^{\mathrm{ef}}$ & $5.80^{\mathrm{g}}$ & $7.14^{\mathrm{C}}$ & $6.88^{\mathrm{de}}$ \\
\hline $50 \mathrm{mg} / \mathrm{l} \mathrm{NAA}$ & $11.92^{d}$ & $8.35^{\mathrm{e}}$ & $4.96^{\mathrm{g}}$ & $6.33^{\mathrm{g}}$ & $4.66^{\dagger}$ & $4.65^{i}$ & $5.76^{\mathrm{d}}$ & $6.09^{d}$ \\
\hline $100 \mathrm{mg} / \mathrm{l} \mathrm{GA} \mathrm{A}_{3}$ & $21.68^{\mathrm{bc}}$ & $14.47^{\mathrm{C}}$ & $7.42^{\mathrm{e}}$ & $9.53^{\mathrm{d}}$ & $5.56 d^{\text {ef }}$ & $6.74^{\mathrm{e}}$ & $8.36^{\mathrm{b}}$ & $9.89^{\mathrm{ab}}$ \\
\hline $150 \mathrm{mg} / \mathrm{l} \mathrm{GA} \mathrm{A}_{3}$ & $22.30^{\mathrm{abc}}$ & $15.75^{\mathrm{bc}}$ & $6.58^{\dagger}$ & $8.57^{\mathrm{e}}$ & $4.46^{\dagger}$ & $5.21^{\mathrm{h}}$ & $8.48^{\mathrm{b}}$ & $9.10^{\mathrm{bc}}$ \\
\hline $0.1 \%$ Boric acid & $24.54^{\mathrm{a}}$ & $17.38^{\mathrm{b}}$ & $8.22^{\mathrm{d}}$ & $10.53^{c}$ & $7.36^{\mathrm{bc}}$ & $7.85^{\mathrm{c}}$ & $7.26^{\mathrm{c}}$ & $9.13^{\mathrm{bc}}$ \\
\hline $0.3 \%$ Boric acid & $25.26^{a}$ & $19.55^{\mathrm{a}}$ & $8.02^{\mathrm{d}}$ & $9.73^{d}$ & $5.98^{\mathrm{de}}$ & $7.09^{d}$ & $5.84^{\mathrm{d}}$ & $8.09^{c}$ \\
\hline $1 \%$ Calcium chloride & $19.64^{c}$ & $15.59^{\mathrm{bc}}$ & $8.34^{\mathrm{d}}$ & $9.24^{\mathrm{d}}$ & $6.56^{\mathrm{bcd}}$ & $7.82^{\mathrm{c}}$ & $7.98^{\mathrm{b}}$ & $8.71^{\mathrm{bc}}$ \\
\hline $2 \%$ Calcium chloride & $20.82^{\mathrm{c}}$ & $16.67^{\mathrm{bc}}$ & $8.00^{\mathrm{d}}$ & $8.42^{\mathrm{e}}$ & $5.38^{\dagger}$ & $6.08^{\dagger}$ & $6.94^{\mathrm{c}}$ & $7.09^{\mathrm{de}}$ \\
\hline 4\% Kaolin & $14.66^{\mathrm{d}}$ & $10.52^{\mathrm{de}}$ & $10.94^{\mathrm{b}}$ & $11.71^{\mathrm{b}}$ & $7.78^{\mathrm{b}}$ & $8.50^{\mathrm{b}}$ & $5.68^{d}$ & $5.58^{\mathrm{e}}$ \\
\hline $6 \%$ Kaolin & $14.74^{\mathrm{d}}$ & $10.65^{\mathrm{e}}$ & $10.38^{\mathrm{C}}$ & $10.56^{c}$ & $5.86^{\text {det }}$ & $7.68^{\mathrm{c}}$ & $4.66^{\mathrm{e}}$ & $4.26^{\dagger}$ \\
\hline LSD at 0.05 & 2.81 & 1.88 & 0.54 & 0.43 & 1.09 & 0.21 & 0.59 & 1.20 \\
\hline
\end{tabular}

\section{B) Yield:}

- Number of fruits/tree:

The effect of the different treatments on fruit number/tree is presented in Table (2). A significant increase in fruit number/tree was obtained in both seasons by foliar application of $0.3 \%$ boric acid (56.40 and $62.20 \%)$, while, significant decrease in fruit number/tree was recorded by $50 \mathrm{mg} / \mathrm{l}$ NAA (25.60 and $33.60 \%$ ), in the first and second seasons, respectively. These results are in agreement with those obtained by Sarrwy et al. (2012), Lal et al. (2013) and Saadati et al. (2016).

- Fruit weight (g):

Data of both seasons showed significant increase in fruit weight by all sprayed chemicals compared to the control treatment, Table (2). The heaviest fruit weight $(577.10$ and $558.53 \mathrm{~g}$ ) in first and second seasons was obtained by applying NAA at $50 \mathrm{mg} / \mathrm{l}$ in both seasons. On the other hand, the control trees showed the lowest values which recorded 326.19 and $315.83 \mathrm{~g}$ in the first and the second seasons, respectively. These results are in agreement with those obtained by Khalil and Aly (2013) and Hegazi et al. (2014).

- Yield (kg/tree):

Data presented in Table (2) showed that all spray treatments increased the yield and the greatest significant fruit yield was found with spraying boric acid at $0.3 \%(24.97 \mathrm{~kg} / \mathrm{tree})$ in the first season and $\mathrm{GA}_{3}$ at $150 \mathrm{mg} / \mathrm{l}(28.18$ $\mathrm{kg} / \mathrm{tree}$ ) in the second season, compared to control treatment which gave the lowest fruit yield (10.55 and $13.16 \mathrm{~kg} / \mathrm{tree})$, in 2016 and 2017 seasons, respectively. These results are in agreement with those obtained by Khalil and Aly (2013). They reported that the application of NAA increased fruit weight and 
yield due to cell elongation by enlargement of vacuoles and loosening of cell wall after increasing cell wall plasticity (Agrawal and Dikshit, 2008).

Table (2). Response of 'Wonderful' pomegranate fruit number/ tree, fruit weight and yield/tree to foliar application of some growth regulators, nutrients elements and kaolin treatments during 2016 and 2017 seasons

\begin{tabular}{lcccccc}
\hline \multirow{2}{*}{ Treatments } & \multicolumn{2}{c}{ Fruit number/tree } & \multicolumn{3}{c}{ Fruit weight $\mathbf{( g )}$} & \multicolumn{2}{c}{ Yield (kg/tree) } \\
\cline { 2 - 7 } & \multicolumn{3}{c}{ Seasons } \\
\cline { 2 - 7 } & $\mathbf{2 0 1 6}$ & $\mathbf{2 0 1 7}$ & $\mathbf{2 0 1 6}$ & $\mathbf{2 0 1 7}$ & $\mathbf{2 0 1 6}$ & $\mathbf{2 0 1 7}$ \\
\hline Control & $32.20 \mathrm{de}$ & $41.80 \mathrm{~h}$ & $326.19 \mathrm{f}$ & $315.83 \mathrm{~h}$ & $10.55 \mathrm{f}$ & $13.16 \mathrm{~g}$ \\
$25 \mathrm{mg} / \mathrm{l} \mathrm{NAA}$ & $28.20 \mathrm{ef}$ & $37.4 \mathrm{i}$ & $482.73 \mathrm{~b}$ & $478.46 \mathrm{c}$ & $13.35 \mathrm{e}$ & $18.18 \mathrm{f}$ \\
$50 \mathrm{mg} / \mathrm{NAA}$ & $25.60 \mathrm{f}$ & $33.6 \mathrm{j}$ & $577.10 \mathrm{a}$ & $558.53 \mathrm{a}$ & $14.42 \mathrm{e}$ & $19.18 \mathrm{ef}$ \\
$100 \mathrm{mg} / \mathrm{GA} \mathrm{G}_{3}$ & $40.60 \mathrm{c}$ & $51.20 \mathrm{e}$ & $442.17 \mathrm{c}$ & $446.16 \mathrm{e}$ & $20.21 \mathrm{c}$ & $23.21 \mathrm{c}$ \\
$150 \mathrm{mg} / \mathrm{l} \mathrm{GA}$ & $45.00 \mathrm{bc}$ & $54.60 \mathrm{~d}$ & $484.40 \mathrm{~b}$ & $512.40 \mathrm{~b}$ & $22.44 \mathrm{~b}$ & $28.18 \mathrm{a}$ \\
$0.1 \%$ Boric acid & $49.40 \mathrm{~b}$ & $59.80 \mathrm{~b}$ & $417.10 \mathrm{e}$ & $415.20 \mathrm{f}$ & $21.23 \mathrm{bc}$ & $24.36 \mathrm{c}$ \\
$0.3 \%$ Boric acid & $56.40 \mathrm{a}$ & $62.20 \mathrm{a}$ & $443.53 \mathrm{c}$ & $445.16 \mathrm{e}$ & $24.97 \mathrm{a}$ & $27.00 \mathrm{ab}$ \\
$1 \%$ Calcium chloride & $39.40 \mathrm{c}$ & $50.20 \mathrm{ef}$ & $426.07 \mathrm{de}$ & $420.46 \mathrm{f}$ & $16.61 \mathrm{~d}$ & $21.30 \mathrm{~d}$ \\
$2 \%$ Calcium chloride & $40.20 \mathrm{c}$ & $56.40 \mathrm{c}$ & $438.17 \mathrm{~cd}$ & $454.46 \mathrm{~d}$ & $17.68 \mathrm{~d}$ & $25.75 \mathrm{~b}$ \\
$\mathbf{4} \%$ Kaolin & $31.80 \mathrm{~d}$ & $46.00 \mathrm{~g}$ & $410.83 \mathrm{e}$ & $402.86 \mathrm{~g}$ & $13.55 \mathrm{e}$ & $18.53 \mathrm{f}$ \\
$6 \%$ Kaolin & $32.20 \mathrm{de}$ & $49.20 \mathrm{f}$ & $416.07 \mathrm{e}$ & $415.60 \mathrm{f}$ & $14.01 \mathrm{e}$ & $20.50 \mathrm{de}$ \\
\hline \multicolumn{1}{c}{ LSD at $\mathbf{0 . 0 5}$} & $\mathbf{5 . 7 1}$ & $\mathbf{1 . 5 7}$ & $\mathbf{1 5 . 4 3}$ & $\mathbf{6 . 2 4}$ & $\mathbf{1 . 3 1}$ & $\mathbf{1 . 3 9}$ \\
\hline
\end{tabular}

Means of each column designated by the same letter are not significantly different at $5 \%$ using least significant difference (L.S.D.)

\section{C) Physical fruit characteristics:}

- Fruit length (cm):

It is apparent from the data presented in Table (3) that the different doses of treatments exerted significant effect on fruit length. The highest fruit length $(9.60 \mathrm{~cm})$ was found under the treatment $50 \mathrm{mg} / \mathrm{l} \mathrm{NAA}$ in the first season and $(9.90 \mathrm{~cm})$ under the treatment $\mathrm{CaCl}_{2}$ at $2 \%$ in the second season, while the lowest fruit length $(7.37$ and $7.20 \%$ ) was recorded under control.

- Fruit diameter (cm):

Data in Table (3) illustrated significant impact of studied treatments on fruit diameter. The data indicated that, significant differences were found between all treatments and control. The maximum fruit diameter (10.53 and $10.53 \mathrm{~cm}$ ) was found in treatment $50 \mathrm{mg} / \mathrm{l}$ NAA and which was followed by the treatment $\mathrm{CaCl}_{2}$ at $2 \%(10.10$ and $10.13 \mathrm{~cm})$. Control (Spraying with tap water) treatment recorded minimum fruit diameter $(8.23$ and $8.10 \mathrm{~cm})$, during both studied seasons. These results are agreement with those obtained by Kishor et al. (2017) and Shanmugasundaram and Balakrishnamurthy (2017). The significant increase in fruit length and fruit diameter obtained may be attributed to nature of auxins (NAA) to stimulate cell division, cell elongation and membrane permeability to water uptake (Chaudhary et al., 2006).

- Fruit volume $\left(\mathrm{cm}^{3}\right)$ :

Results in Table (3) indicated that, the maximum fruit volume was observed in the treatment $50 \mathrm{mg} / \mathrm{I} \mathrm{NAA} \mathrm{(593.20} \mathrm{and} 578.72 \mathrm{~cm}^{3}$ ), as compared with the control treatment which recorded the minimum fruit volume (335.53 and 
$324.16 \mathrm{~cm}^{3}$ ) in the first and second seasons, respectively. These results are in agreement with those obtained by Shanmugasundaram and Balakrishnamurthy (2017) and Singh et al. (2017).

- Grain weight (g):

The observations recorded on fruit grain are presented in Table (3), results revealed that all treatments had significant effect on fruit grain. The highest fruit grain was noted with $50 \mathrm{mg} / \mathrm{l} \mathrm{NAA} \mathrm{(411.57} \mathrm{and} 365.70 \mathrm{~g}$ ), while, the lowest fruit grain (220.00 and $184.10 \mathrm{~g}$ ) was recorded with control treatment, during both seasons, respectively. These results are in agreement with those obtained by Reddy and Prasad (2012) on pomegranate cv. 'Ganesh' and Anawal et al. (2015) on cv. 'Bhagwa', whereas increase in grain weight by NAA was also reported by Rahemi and Atahosseini (2004) on cv. 'Shishep Cup'.

- Juice (\%):

It is evident from Table (3) that different treatments increased the juice percentage compared with the control increased significantly with the increase dose of Kaolin. The significantly highest juice percentage (77.32 and $79.07 \%$ ) was recorded with $6 \%$ Kaolin, while the control treatment recorded the lowest juice percentage (70.86 and $69.36 \%$ ), during both seasons, respectively. These results are in agreement with those obtained by Khalil and Aly (2013). Increased fruit juice as a result of kaolin treatments may be due to its protective effect from high temperature and reflection of solar radiation, especially UV wavelengths, which led to reduce heat stress on fruits, enhance fruit water content by decreasing transpiration from fruit surface (Glenn and Puterka, 2005).

\section{D) Chemical fruit characteristics:}

- Total soluble solids (TSS \%):

The effect of different sprayed substances on TSS\% is presented in Table (4). A significant increase in total soluble solids (TSS) in comparison with the control was obtained in both seasons by all treatments. Calcium chloride at $2 \%$ recorded the highest TSS content $(17.26 \%)$ in the first season and boric acid at $0.3 \%(18.23 \%)$ in the second season, respectively. Control treatment recorded the lowest total soluble solids (15.26 and $16.07 \%)$, during both seasons under this study. These results are in agreement with those obtained by Anawal et al. (2015), Hikal et al. (2017) and Davarpanaha et al. (2018). Improvement in TSS of fruits due to NAA and $\mathrm{GA}_{3}$ spray may be explained from the fact that application of these growth regulators after fruit set probably improved the physiology of leaves, thereby causing better translocation of vital components in the fruit and assimilation/utilization of photosynthates by the developing fruit (Pandey, 1999).

- Total acidity (\%):

Data in Table (4) indicated that, fruit acidity percentage was significantly decreased by applying calcium chloride at $2 \%$ in the first season $(0.77 \%)$ and $\mathrm{GA}_{3}$ at $150 \mathrm{mg} / \mathrm{l}(0.72 \%)$ in the second season, respectively. On the other hand, the highest fruit acidity percentage (1.47 and $1.21 \%)$ was obtained from 
the control plants in both seasons. These results are in agreement with those obtained by Kishor et al. (2017) and Davarpanaha et al. (2018).

- Total sugars (\%):

Results presented in Table (4) showed significant increase in total sugars with all treatments in comparison with the control in both seasons. NAA at 50 $\mathrm{mg} / \mathrm{l}$ recorded the highest sugars content $(11.96 \%)$ in the first season and $0.3 \%$ boric acid $(13.55 \%)$ in the second season. On the other hand, control treatment recorded the lowest sugars content (8.78 and $9.00 \%$ ) during 2016 and 2017 seasons, respectively. These results are in agreement with those obtained by Anawal et al. (2015) on pomegranate cv. 'Bhagwa' who indicated that application of NAA $40 \mathrm{mg} / \mathrm{l}$ resulted in increase in reducing, non-reducing and total sugars.

- Reducing sugars (\%):

It was appeared from data presented in Table (4) that the all treatments significantly influenced the reducing sugars \%. The maximum reducing sugar $(6.57 \%)$ was found under the treatment NAA at $50 \mathrm{mg} / \mathrm{l}$ in the first season and $0.3 \%$ boric acid $(9.88 \%)$ in the second season. The minimum reducing sugar $\%$ was recorded under control (5.43 and $6.69 \%)$ during both seasons.

- Vitamin C (mg/100 ml juice):

It is evident from the data presented in Table (4) that foliar application of $\mathrm{GA}_{3}$ at $150 \mathrm{mg} / \mathrm{l}$ recorded the maximum ascorbic acid content $(16.00 \mathrm{mg} / 100 \mathrm{ml}$ juice) in the first season and calcium chloride at $2 \%(20.33 \mathrm{mg} / 100 \mathrm{ml}$ juice $)$ in the second season, while, the control treatment recorded the minimum ascorbic acid content (10.67 and $11.67 \mathrm{mg} / 100 \mathrm{ml}$ juice) in both seasons. These results are in agreement with those obtained by Korkmaz and Aşkin (2015), Hikal et al. (2017), Singh et al. (2017).

- Anthocyanin (mg/100g):

Results presented in Table (4) showed significant increase in anthocyanin with all treatments in comparison with the control in both seasons. NAA at $50 \mathrm{mg} / \mathrm{l}$ recorded the maximum anthocyanin content $(0.84 \mathrm{mg} / 100 \mathrm{~g})$ than all other treatments in the first season and boric acid at $0.3 \%(0.88$ $\mathrm{mg} / 100 \mathrm{~g}$ ) in the second season, while, the control treatment recorded the minimum anthocyanin content $(0.51$ and $0.42 \mathrm{mg} / 100 \mathrm{~g})$ in both seasons. These results are in agreement with those obtained by Kishor et al. (2016) and Attia (2017). 
Table (3). Response of 'Wonderful' pomegranate fruit physical parameters to foliar application of some growth regulators, nutrients elements and kaolin treatments during 2016 and 2017 seasons

\begin{tabular}{|c|c|c|c|c|c|c|c|c|c|c|}
\hline \multirow{3}{*}{ Treatments } & \multicolumn{2}{|c|}{$\begin{array}{l}\text { Fruit length } \\
(\mathrm{cm})\end{array}$} & \multirow{2}{*}{\multicolumn{2}{|c|}{$\begin{array}{l}\text { Fruit diameter } \\
(\mathrm{cm})\end{array}$}} & \multirow{2}{*}{\multicolumn{2}{|c|}{$\begin{array}{c}\begin{array}{c}\text { Fruit volume } \\
\left(\mathrm{cm}^{3}\right)\end{array} \\
\text { Seasons } \\
\end{array}$}} & \multicolumn{2}{|c|}{$\begin{array}{c}\text { Grain weight } \\
\text { (g) }\end{array}$} & \multicolumn{2}{|c|}{$\begin{array}{c}\text { Juice } \\
(\%)\end{array}$} \\
\hline & & & & & & & & & & \\
\hline & 2016 & 2017 & 2016 & 2017 & 2016 & 2017 & 2016 & 2017 & 2016 & 2017 \\
\hline Control & $7.37^{9}$ & $7.20^{9}$ & $8.23 f$ & $8.10^{9}$ & $335.53^{9}$ & $324.16^{\mathrm{h}}$ & $220.00^{\mathrm{e}}$ & $184.10^{\mathrm{h}}$ & $70.86 d$ & $69.36 \mathrm{~g}$ \\
\hline $25 \mathrm{mg} / \mathrm{l} \mathrm{NAA}$ & $9.43^{\mathrm{abc}}$ & $9.13^{\mathrm{C}}$ & $10.23^{b}$ & $10.23^{b}$ & $498.83^{b}$ & $487.75^{\mathrm{C}}$ & $335.63^{b}$ & $299.93^{d}$ & $73.68 c$ & 72.86ef \\
\hline $50 \mathrm{mg} / \mathrm{l} \mathrm{NAA}$ & $9.60^{\mathrm{a}}$ & $8.56^{\mathrm{C}}$ & $10.53^{a}$ & $10.53^{a}$ & $593.20^{a}$ & $578.72^{a}$ & $411.57^{a}$ & $365.70^{a}$ & $76.53 a b$ & $75.36 c$ \\
\hline $100 \mathrm{mg} / \mathrm{l} \mathrm{GA}_{3}$ & $9.23^{\mathrm{de}}$ & $9.13^{c}$ & $9.63^{d}$ & $9.56^{d}$ & $466.50^{c}$ & $454.68^{\mathrm{e}}$ & $302.00^{\mathrm{cd}}$ & $298.16^{\dagger}$ & 73.57c & 73.52de \\
\hline $150 \mathrm{mg} / \mathrm{l} \mathrm{GA} A_{3}$ & $9.53^{a b c}$ & $9.56^{\mathrm{b}}$ & $9.87^{\mathrm{cd}}$ & $10.13^{b}$ & $510.53^{b}$ & $519.82^{b}$ & $330.10^{b}$ & $343.16^{b}$ & $76.42 a b$ & $75.82 c$ \\
\hline $0.1 \%$ Boric acid & $9.23^{\mathrm{de}}$ & $8.03^{f}$ & $9.70^{d}$ & $8.86^{f}$ & $437.77^{\mathrm{ef}}$ & $425.05^{\dagger}$ & $288.70^{d}$ & $277.83^{\mathrm{e}}$ & $74.54 c$ & 72.37ef \\
\hline $0.3 \%$ Boric acid & $9.40^{\mathrm{bcd}}$ & $8.63^{d}$ & $9.83^{d}$ & $9.43^{d}$ & $466.53^{c}$ & $454.64^{\mathrm{e}}$ & $312.23^{c}$ & $298.73^{d}$ & $75.89 b$ & $73.81 d$ \\
\hline $1 \%$ Calcium chloride & $9.37^{\mathrm{cd}}$ & $9.30^{\mathrm{b}}$ & $9.80^{d}$ & $9.76^{c}$ & $450.30^{\text {de }}$ & $428.27^{f}$ & $291.67^{d}$ & $278.86^{\mathrm{e}}$ & $74.09 c$ & $75.32 \mathrm{c}$ \\
\hline $2 \%$ Calcium chloride & $9.57^{\mathrm{ab}}$ & $9.90^{a}$ & $10.10^{b c}$ & $10.13^{b}$ & $462.87^{\mathrm{cd}}$ & $465.13^{d}$ & $289.53^{d}$ & $305.53^{c}$ & $76.53 \mathrm{ab}$ & $78.34 a b$ \\
\hline $4 \%$ Kaolin & $8.47^{\dagger}$ & $8.43^{\mathrm{e}}$ & $9.27^{\mathrm{e}}$ & $9.10^{\mathrm{e}}$ & $431.07^{f}$ & $415.21^{\mathrm{g}}$ & $290.30^{d}$ & $249.10^{g}$ & $76.83 a b$ & $78.22 b$ \\
\hline $6 \%$ Kaolin & $9.10^{\mathrm{e}}$ & $9.16^{\mathrm{C}}$ & $9.80^{d}$ & $9.73^{C}$ & $436.20^{f}$ & $427.18^{f}$ & $290.23^{d}$ & $258.53^{f}$ & $77.32 a$ & $79.07 a$ \\
\hline LSD at 0.05 & 0.19 & 0.17 & 0.24 & 0.14 & 14.01 & 7.18 & 13.62 & 2.72 & 1.05 & 0.78 \\
\hline
\end{tabular}

Means of each column designated by the same letter are not significantly different at $5 \%$ using least significant difference (L.S.D.) 
Table (4). Response of 'Wonderful' pomegranate fruit chemical parameters to foliar application of some growth regulators, nutrients elements and kaolin treatments during 2016 and 2017 seasons

\begin{tabular}{|c|c|c|c|c|c|c|c|c|c|c|c|c|}
\hline \multirow[t]{3}{*}{ Treatments } & \multicolumn{2}{|c|}{$\begin{array}{l}\text { TSS } \\
\text { (\%) }\end{array}$} & \multicolumn{2}{|c|}{$\begin{array}{c}\text { Acidity } \\
(\%)\end{array}$} & \multicolumn{2}{|c|}{$\begin{array}{c}\text { Total sugars } \\
(\%)\end{array}$} & \multirow{2}{*}{\multicolumn{2}{|c|}{$\begin{array}{c}\text { Reducing } \\
\text { sugars } \\
(\%)\end{array}$}} & \multicolumn{2}{|c|}{$\begin{array}{c}\text { Vitamin C } \\
\text { (mg/100 ml juice) }\end{array}$} & \multicolumn{2}{|c|}{$\begin{array}{l}\text { Anthocyanin } \\
\text { (mg/100g) }\end{array}$} \\
\hline & & & & & & $\mathrm{Se}$ & & & & & & \\
\hline & 2016 & 7 & 2 & 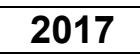 & 6 & 2017 & 2016 & 2017 & 2016 & 2017 & 2016 & 2017 \\
\hline Con & $15.26 f$ & $16.07 \mathrm{~h}$ & $1.47 a$ & & & & & $6.69 \mathrm{j}$ & & & & $0.42 \mathrm{j}$ \\
\hline & - & & & & & & & & & & & \\
\hline & & & & & & & & & & & & \\
\hline 100 & $17.00 \mathrm{ab}$ & $17.30 \mathrm{~d}$ & & $0.77 \mathrm{e}$ & & & & $7.52 \mathrm{~h}$ & $a b c$ & & $0.66 d$ & $0.61 \mathrm{gh}$ \\
\hline $150 r$ & 17.20ab & $17.57 \mathrm{c}$ & $93 c$ & $0.72 f$ & 10 & 10. & $6.42 a$ & $7.89 f$ & & & $0.73 c$ & $0.69 d$ \\
\hline $0.1 \%$ Bori & $16.10 \mathrm{e}$ & $17.27 \mathrm{de}$ & $0.92 c$ & $0.87 \mathrm{bc}$ & $9.76 \mathrm{e}$ & & $6.29 b$ & $9.20 \mathrm{~b}$ & & & $0.64 \mathrm{de}$ & $0.82 b$ \\
\hline $0.3 \%$ Boric acid & $16.40 \mathrm{de}$ & $18.23 a$ & $0.90 c$ & & & & & & & cde & & $0.88 a$ \\
\hline $1 \%$ Calcium chloride & & & & & & & & & & & & \\
\hline & & & & & & & & & & & & \\
\hline & & & & & & & & & & & & $7 i$ \\
\hline $6 \% \mathrm{Kac}$ & b & & 0.8 & & & & $6.38 b$ & $8.74 d$ & bc & & $0.63 \mathrm{de}$ & $0.60 \mathrm{~h}$ \\
\hline LSD at 0.05 & 0.35 & 0.16 & 0.09 & 0.02 & 0.47 & 0.60 & 0.16 & 0.08 & 1.50 & 1.22 & 0.04 & 0.07 \\
\hline
\end{tabular}

Means of each column designated by the same letter are not significantly different at $5 \%$ using least significant difference (L.S.D.) 


\section{CONCLUSION}

From the results of the preset experiment, it could be concluded that, 50 mg/l NAA followed by boric acid at $0.3 \%$, calcium chloride at $2 \%$ and kaolin at $6 \%$ gave the highest fruit set, fruit cracking and sunburn percentages, yield, and fruit quality of 'Wonderful' pomegranate trees (Punica granatum L.).

\section{REFERENCES}

Adsule, R.N. and N.B. Patil (1995). Handbook of Fruit Science and Technology. In: Salunkhe, D.K., Kadam, S.S. (Eds.), Pomegranate. Marcel Dekker Publishers, New York, pp. 455-464.

Agrawal, S., and S.N. Dikshit (2008). Studies on the effect of plant growth regulators on growth and yield of sapota (Achras sapota L.) cv. 'Cricket Ball'. Indian J. Agric. Res., 42: 207-211.

Almeida, I.M.L., R. Domingos and E.O. Ono (2004). Application of plant growth regulators at pre- harvest for fruit development of Pera oranges. Brazilian Arch. Biol. \& Tech. ISSN: 1678-4324.

Ameen Al-Imam, N.M. (2009). Effect of compound fertilizer and foliar application of iron, gibberellic acid on the growth and yield of Salemy pomegranate cultivar (Punica granatum L.) $2^{\text {nd }}$ study the yield and its physical components. Mesopotamia J. Agric., 37(2): 17-24.

Amezquita, N., H.E. Balaguera-Lopez and J.G. Alvarez Herrera (2008). Effect of pre-harvest application of gibberellins and calcium on production, fruit quality and cracking of cape gooseberry (Physalis peruviana L.). Rev. Colombiana de Ciencias Hort., 2: 133-144.

Anawal, V.V., P. Narayanaswamy and S.D. Ekabote (2015). Effects of plant growth regulators on fruit set and yield of pomegranate cv. 'Bhagwa'. Int. J. Sci. Res., 220-222.

AOAC (1985). Official Methods of Analysis pp 490-510. Association of Official Analytical ChemistsWashington, D. C.

Asgharzade, A. and M. Babaeian (2012). Foliar application of calcium borate and micronutrients effects on some characters of apple fruits in Shirvan Region. Ann. Biol. Res., 3 (1): 527-533.

Attia, S. M. (2017). Manipulation of splitting, sunburn and enhancing coloration of 'Wonderful' pomegranates by pre-harvest foliar applications. J. Agric. and Res., 3(5): 1-9.

Bakeer, S.M. (2016). Effect of ammonium nitrate fertilizer and calcium chloride foliar spray on fruit cracking and sunburn of 'Manfalouty' pomegranate trees. Sci. Hort., 209: 300-308.

Canli, F.A., M. Sahin, S. Ercisli, O. Yilmaz, N. Temurtas and M. Pektas (2015). Harvest and postharvest quality of sweet cherry are improved by pre-harvest benzyladenine and benzyladenine plus gibberellin applications. J. Appl. Bot. Food Qual., 88: 255-258.

Chaudhary, B.R., M.D. Sharma, S.M. Shakya and D.M. Gautam (2006). Effect of plant growth regulators on growth, yield and quality of chilly (Capsicum annuum L.) at Rampur, Chitwan. J. Inst. Agric. Anim. Sci., 27: 65-68. 
Chen, B. M. and W. M. Mellenthin (1981). Effect of harvest date on ripening capacity and post-harvest life of cv. 'Anjou' pears trees. J. Amer. Soc. Hort. Sci., 106: 38-42.

Cheour, F., C. Willemot, J. Arul, Y. Desjardins, J. Makhlouf, P.M. Charest and A. Gosselim (1990). Foliar application of calcium chloride delays postharvest ripening strawberry. J.A.M. Soc. Hort. Sci., 115: 789-792.

Cline, J.A. and M. Trought (2007). Effect of gibberellic acid on fruit cracking and quality of Bing and Sam sweet cherries. Canadian J. Plant Sci., 87: 545-550.

Davarpanaha, S., A. Tehranifara, J. Abadíab, J. Valb, G. Davarynejada, M. Aranc and R. Khorassanid (2018). Foliar calcium fertilization reduces fruit cracking in pomegranate (Punica granatum L.) cv. 'Ardestani'. Sci. Hort., 230: 86-91.

El-Mahdy, T. K.R., A. K. A. Mohamed and N. I.A. Mohamed (2009). Effect of flower thinning and spraying with gibberellic acid and ethephon on yield and fruit quality of 'Manfalouty' pomegranate cultivar. Assiut J. Agric. Sci., 40 (4): 69-91.

El-Sheikh, M.H., S.A.A. Khafgy and S.S. Zaied (2007). Effect of foliar application with some micronutrients on leaf mineral content, yield and fruit quality of Florida prince and Desert red peach trees. J. Agric. Biol. Sci., 3: 309-315.

Ennab, H.A., S.A. El-Sayed and M.M.S. Abo El-Enin (2017). Effect of kaolin applications on fruit sunburn, yield and fruit quality of Balady mandarin (Citrus reticulata, Blanco). Menoufia J. Plant Prod., 2: 129-138.

Glenn, D.M. and E. Prado (2002). A reflective, processed-kaolin particle film affects fruit temperature, radiation reflection, and solar injury in apple. J. Am. Soc. Hort. Sci., 127(2): 188-193.

Glenn, D.M. and G.J. Puterka (2005). Particle films: a new technology for agriculture. Hort. Rev., 31: 1-44.

Hassan, H. S. A. (2000). Morphological and Physiological studies on flowering, pollination and fruiting of Picual olive trees. PhD Thesis, Fac. Agric., Cairo Univ., Egypt.

Hegazi, A., N.R. Samra, E.E.T. El-Baz, Bahan M. Khalil and M.S. Gawish (2014). Improving fruit quality of 'Manfalouty' and 'Wonderfull' pomegranates by using bagging and some spray treatments with gibberellic acid, calcium chloride and kaolin. J. Plant Prod. Mansoura Univ., 5 (5): 779-792.

Hikal, A. R. F., M. A. Ibrahim and R. A. Abdelaziz (2017). Effect of different treatments of calcium and boron on productivity and fruit quality of navel orange fruits. Egypt. J. Hort., 44 (1): 119- 126.

Khalil, H. A. and H. S.H. Aly (2013). Cracking and fruit quality of pomegranate (Punica granatum L.) as affected by pre-harvest sprays of some growth regulators and mineral nutrients. J. Hort. Sci. Ornam. Plants, 5(2): 71-76.

Kishor, S., S. Maji, A. Govind, R. Yadav, K. R. Meena and A. Kumar (2016). Influence of plant bio-regulators and chemicals on yield and fruit quality of young pomegranate (Punica granatum L.) cv. 'Bhagwa'. Environ. \& Ecol., 34 (4D): 2566-2570. 
Kishor, S., S. Maji, M.L. Meena, H. Deepa, D. S Kishor and S. Kumar (2017). Effect of plant bio-regulators and chemicals on fruit physico-chemical traits of pomegranate (Punica granatum L.) cv. 'Bhagwa'. J. Pharm. and Phyto., 6(4): 1573-1575.

Korkmaz N. and M.A. Aşkın (2015). Effects of calcium and boron foliar application on pomegranate (Punica granatum L.) fruit quality, yield, and seasonal changes of leaf mineral nutrition. Acta Hort., 9(4): 57-61.

Kumar, K., R. Pinder, J.S. Dabas, B. Yadav and S. Rana (2017). Effect of growth regulators and micronutrients on fruit cracking and fruit yield in pomegranate. Ind. J. Agric. Res., 51 (3): 272-276.

Lal, N., R.P. Das and L. R. Verma (2013). Effect of plant growth regulators on flowering and fruit growth of guava (Psidium guajava L.) cv. Allahabad Safeda. Asian J. Hort., 8(1): 54-56.

Legua, P., P. Melgarejo, H. Abdelmajid, J.J. Martínez, R. Martínez, H. Ilham, H. Hafida and F. Hernandez (2012). Total phenols and antioxidant capacity in 10 Moroccan pomegranate varieties. J. Food Sci., 71: 115120.

Malik, C. P. and M. B. Singh (1980). Plant enzymology and Histoenzymology. A Text Manual, Kalyani publishers, New Delhi.

Marschner, H. (2012). Mineral Nutrition of Higher Plants. Academic Press Limited Harcourt Brace and Company, Publishers, London, pp. 347-364.

Melgarejo, P., J.J. Martı'nez, F. Herna'ndez, R. Martínez-Font, P. Barrows and A. Erez (2004). Kaolin treatment to reduce pomegranate sunburn. Sci. Hort., 100: 349-353.

Merwad, M. A., R.A. Eisa and A.M. M. Merwad (2016). Effect of $\mathrm{GA}_{3}$ and some nutrients on pomegranate under South Sinai governorate conditions. Int. J. Chem. Tech. Res., 9(8): 104-113.

Ministry of Agriculture and Land Reclamation (2013). Agricultural Economic Bulletins. Ministry of Agric. Egypt.

Mitra, S.K. (1997). Post-harvest Physiology and Storage of Tropical and SubTropical Fruits. CAB, INT., Nadia, West Gengal, India, pp. 84-122.

Mozaffarifard, M., M. Rahemi and E. AsImoshtaghi (2017). Effect of kaolin application on some physiological characteristics and sunburn in 'Washington Navel' orange. Iranian J. Hort. Sci. \& Tech., 18(1):67-80.

Naik, S.K. and P.K. Chand (2011). Tissue culture-mediated biotechnological intervention in pomegranate: a Review. Plant Cell Rep., 30: 707-721.

Pandey, V. (1999). Effect of NAA and $\mathrm{GA}_{3}$ spray on fruit retention, growth, yield and quality of ber cv. Banarasi Karka. Orissa J. Hort., 27:69-73.

Pooviah, B.W. (1979). Role of calcium in ripening and senescence. Commun. Soil Sci. Plant Anal., 10: 83-88.

Prajapati, R.D., H.N. Laua, P.D. Solanki and N.S. Parekh (2016). Effect of plant growth regulators on flowering, fruiting, yield and quality parameters of custard apple (Annona squmosa L.). Ecology, Environ. \& Conservation, 22: 177-179.

Rabino, I., A.L. Mancinelli and K.H. Kuzmanoff (1977). Photocontrol of anthocyanin synthesis VI. Spectral sensitivity, irradiance dependence and reciprocity relationship. Plant Phy., 59: 569- 573. 
Rahemi, M. and A. Atahosseini (2004). Effect of plant growth regulators on fruit characteristics and leaf area of pomegranate cv. 'Shisheh Cup'. Acta Hort., 662: 313-317.

Reddy, P.a. and D. M. Prasad (2012). Effect of plant growth regulators on fruit characters and yield of pomegranate (Punica granatum L.) cV. 'Ganesh'. Int. J. Plant Animal \& Environ. Sci., 2:91-93.

Saadati, S., N. Moallemi, S.M.H. Mortazavi and S.M. Seyyednejad (2016). Foliar applications of zinc and boron on fruit set and some fruit quality of olive. Crop Res., 51: 1-5.

Salgado, J.M., T.R.B. Ferreira, F. O. Biazotto, C.T. S. Dias (2012). Increased antioxidant content in juice enriched with dried extract of pomegranate (Punica granatum L.) peel. Plant Foods Hum. Nutr., 67: 39-43.

Sarrwy, S.M.A., E.G. Gadalla and E.A.M. Mostafa (2012). Effect of calcium nitrate and boric acid sprays on fruit set, yield and fruit quality of cV. Amhat date palm. World J. Agric. Sci., 8 (5): 506-515.

Schupp, J., E. Fallahi and I.J. Chun (2002). Effect of surround particle film on fruit sunburn, maturity and quality of 'Fuji' and 'Honeycrisp' apples. New York Fruit Quarterly, 10: 9-11.

Shanmugasundaram, T. and G. Balakrishnamurthy (2017). Exploitation of plant growth substances for improving the yield and quality of pomegranate under ultra-high density planting. Int. J. Curr. Microbiol. App. Sci., 6(3): 102-109.

Sheikh, M. K. and N. Manjula (2012). Effect of chemicals on control of fruit cracking in pomegranate (Punica granatum L.) var. 'Ganesh'. In: Melgarejo P. (ed.), Valero D. (ed.). II Int. Symp. on the Pomegranate. Zaragoza: CIHEAM / Universidad Miguel Hernández, p. 133-135.

Singh, K., M. Sharma and S. K. Singh (2017). Effect of plant growth regulators on fruit yield and quality of guava (Psidium guajava) cv. 'Allahabad Safeda'. J. Pure \& App Microb., 11(2):1149-1154.

Snedecor, G. W and W. G. Cochran (1990). Statistical Methods. Oxford and J. B. H. Bub. Com. $6^{\text {th }}$ Edition. pp: 507.

Suman, M., P.D. Sangma, D.R. Meghawal and O.P. Sahu (2017). Effect of plant growth regulators on fruit crops. J. Pharm. \& Phyto., 6: 331-337.

Viuda-Martos, M., J. Fernandez-Lopez and J.A. Perez-Alvarez (2010). Pomegranate and its many functional components as related to human health: a review. Compr. Rev. Food Sci. Saf., 9: 635-654.

Viuda-Martos, M., J.A. Pérez-Álvarez, E. Sendra and J. Fernández-López (2013). In vitro antioxidant properties of pomegranate (Punica granatum L.) peel powder extract obtained as co-product in the juice extraction process. J. Food Process. Preserv., 37: 2.

Yilmaz, C. and A. I. Özgüven (2016). Hormone physiology of pre-harvest fruit cracking in pomegranate (Punica granatum L.). Acta Hort., 545-550.

Westwood, M.N. (1978). Temperate Zone Pomology. W.H. Freeman and Company. San Francisco. 


\section{الملخص العربي \\ تأثير بعض منظمات النمو والعناصر الغذائية والكاولين على تثقق وجودة ثمار الرمان صنف 'وندرفول'}

\section{"محمد محمد محمد حرحش "محمود أحمد محمد علي "* نجوى أبوالمجد عبدالمجيا أحمد بطم سالم بن هيفاء"****}

$$
\text { " قسم الإنتاج النباتي - كلية الزراعة سابا باشا - جامعة الأسكندرية. معرث البساتين - مركز البحوث الزراعية - جيزة - مصر. }
$$

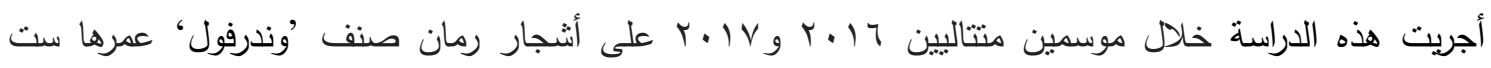

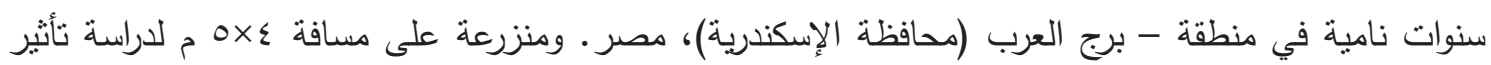
بعض منظمات النمو والعناصر الغذائية والكاولين على تشقق وجودة ثمار الرمان صنف 'وندرفول، ـ وقد تم تصميم التجربة بنظام القطاعات العشوائية الكاملة بخمس مكررات. ويحتوي كل قطاع على ل1 1 معاملة (كنترول، نفتالين

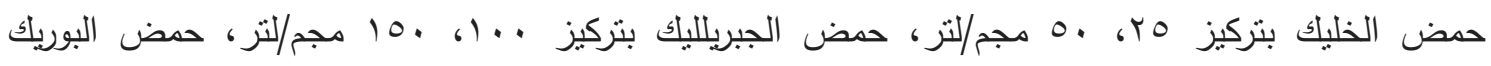

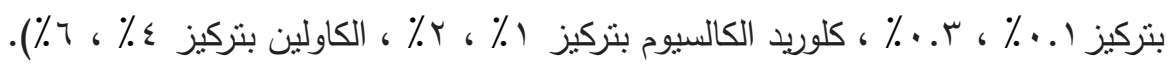

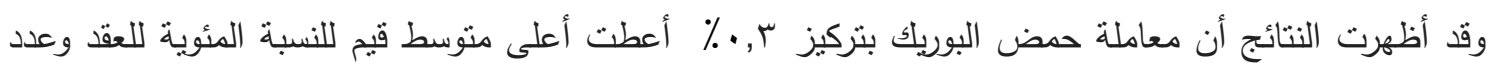

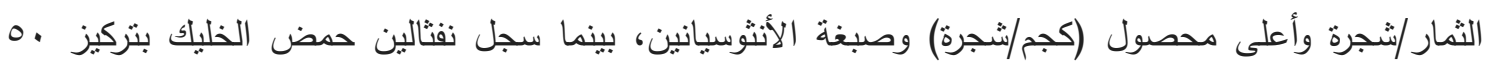

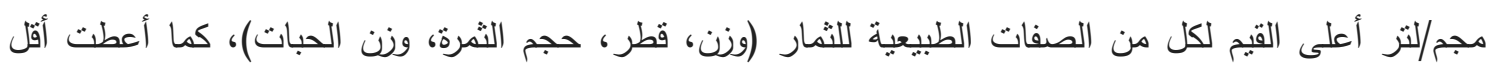

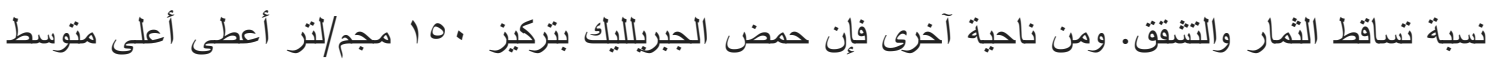
للمحصول (كجم/شجرة) في الموسم الثاني وأقل نسبة لتشقق الثمار في الموسم الأول بينما أعطى كلوريد الكالسيوم

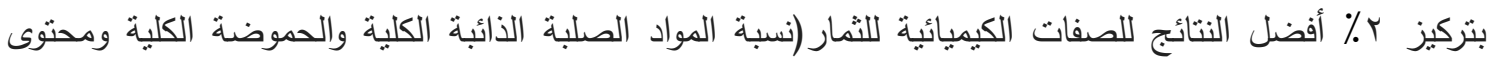
فيتامين C) واحتوت ثمار جميع المعاملات على أعلى نسبة من السكريات الكلية والمختزلة مقارنة بالكنترول وأخيراً

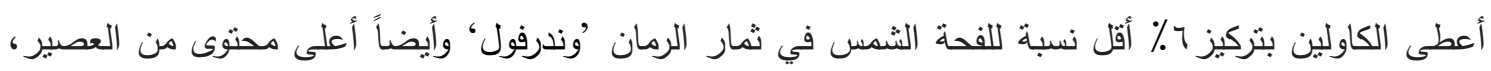
مقارنة بالكنترول وغيرها من المعاملات الآخرى وذللك خلال موسمي الدراسة. 
